\title{
Perbandingan Perkiraan Debit Puncak Banjir Menggunakan Metode Nakayasu dan Metode FSR Jawa Sumatera untuk DAS Dombo Sayung
}

\author{
Muhammad Syarifudin ${ }^{1}$, Karuniadi Satrijo Utomo ${ }^{2}$ \\ 1,2 Teknik Sipil, Fakultas Teknik, Universitas Negeri Semarang - Kampus Sekaran Gunungpati Semarang 50229 \\ e-mail corresponding author : muhammadsyarifudin2604@gmail.com.
}

\begin{abstract}
ABSTRAK
Banjir merupakan salah satu bentuk bencana alam yang hingga saat ini masih belum dapat diselesaikan. Dampak banjir tidak hanya kerugian infrastruktur berupa jalan dan fasilitas umum akan tetapi kerugian materil menjadi bagian dari dampak yang merugikan bagi masyarakan. Padahal, bagi sebagian warga di Semarang dan Kabupaten Demak, banjir menjadi persoalan rutin pada musim penghujan. Daerah yang menjadi langganan banjir di Demak yaitu daerah Sayung, Karang Asem dan Mranggen. Banjir di daerah tersebut sulit diatasi bahkan semakin lama persoalan banjir tersebut semakin parah dan meluas. Dengan demikian penelitian ini bertujuan untuk mengetahui perbandingan perkiraan debit puncak banjir melalui dua metode yang berbeda. Berdasarkan pada hasil maka mitigasi bencana juga dapat ditingkatkan. Metode dalam penelitian ini menggunakan metode Nakayasu dan FSR Jawa Sumatera untuk mengukur debit puncak banjir dengan menggunakan rentang data curah hujan 10 tahun. Adapun hasil analisis menunjukkan bahwa debit banjir yang dianalisis dengan menggunakan metode Nakayasu menghasilkan debit banjir lebih besar daripada analisis debit banjir menggunakan FSR Jawa Sumatera. Hasil analisis dengan menggunakan metode Nakayasu diperoleh nilai terbesar untuk Sungai Penggaron $270,4 \mathrm{~m}^{3 /}$ detik. Sungai Dombo Sayung 296,4 m³/detik dan Sugai Dolok 332,2 m³ detik. Adapun, untuk Metode FSR Jawa Sumatera diperoleh nilai terbesar untuk Sungai Penggaron 112,7 $\mathrm{m}^{3 /}$ detik. Sungai Dombo Sayung 239,7 m³/detik dan Sugai Dolok 632,1 m³/detik.
\end{abstract}

Kata kunci : debit banjir; dombo sayung; FSR Jawa Sumatera; nakayasu

\begin{abstract}
Flooding is a form of natural disaster that has yet to be resolved. The impact of flooding is the loss of infrastructure in roads and public facilities, but a material loss is part of the community's detrimental impact. For some residents in Semarang and Demak Regency, flooding is a routine problem during the rainy season. A reas that are regularly flooded in Demak are Sayung, Karang Asem, and Mranggen. Floods in the area are challenging to overcome, even if flooding is getting worse and broader. Thus this study aims to determine the comparison of the estimated peak flood discharge through two different methods. Based on the results, disaster mitigation can also be improved. This study used Nakayasu and Java Sumatera FSR to measure the peak flood discharge using a ten-year rainfall data range. The analysis results show that the flood discharge analyzed using the Nakayasu method produces a more massive flood discharge than the flood discharge analysis using the Java Sumatra FSR. The analysis results using the Nakayasu method obtained the most significant value for the Penggaron River $270.4 \mathrm{~m} 3 /$ second. Sungai Dombo Sayung $296.4 \mathrm{~m} 3 /$ second and Sugai Dolok $332.2 \mathrm{~m} 3 /$ second. Meanwbile, for the Java Sumatra FSR Method, the most significant value was obtained for the Penggaron River 112.7 m3/second. Sungai Dombo Sayung $239.7 \mathrm{m3} /$ second and Sugai Dolok $632.1 \mathrm{~m} 3 /$ second.
\end{abstract}

Keywords : dombo sayung; flood discharge; java sumatera FSR; nakayasu

Cara mengutip: Syarifudin, M., dan Utomo, K. S. (2020). Perbandingan Perkiraan Debit Puncak

Menggunakan Metode Nakayasu dan Metode FSR Jawa Sumatera untuk DAS Dombo Sayung. Reka Buana :

Jurnal Ilmiah Teknik Sipil dan Teknik Kimia, 5(2), 135-146. http://dx.doi.org/10.33366/rekabuana.v5i2.1894 


\section{PENDAHULUAN}

Banjir merupakan bentuk dari bencana alam yang hingga saat ini masih belum dapat diselesaikan. Dampak banjir tidak hanya kerugian infrastruktur berupa jalan dan fasilitas masyarakat akan tetapi kerugian materil juga sangat merugikan bagi masyarakat. Bahkan bagi sebagian warga di Kota Semarang dan Kabupaten Demak banjir merupakan sebuah persoalan rutin pada musim penghujan. Daerah Demak yang menjadi langganan banjir yaitu daerah Sayung, Karang Asem dan Mranggen. Banjir tersebut sulit diatasi bahkan semakin lama persoalan banjir pada daerah tersebut semakin parah. Penyebab semakin parahnya banjir di wilayah tersebut karena disertai dampak erosi dan adanya penurun permukaan tanah di kota bagian utara[1]. Selain itu permasalahan banjir di daerah tersebut juga dipengaruhi adanya fenomena air pasang (ROB) dan lumpur yang mengendap. Sehingga berakibat pada terjadinya pendangkalan sungai [2].

Pendangkalan sungai juga terjadi di Sungai Wonokerto yang berada di Desa Wonokerto merupakan sebuah gambaran bahwa sungai-sungai yang berada di Kabupaten Demak banyak mengalami pendangkalan. Pendangkalan sungai tersebut disebabkan adanya endapan dari partikel yang ikut mengalir bersama arus sungai. Partikel yang dimaksud salah satunya sampah, akan tetapi yang mendominasi adalah endapan partikel berupa tanah akibat ROB. Adanya pendangkalan tersebut menjadi satu masalah lingkungan yaitu banjir. Sungai tidak mampu memuat seluruh volume air, sehingga terjadi peluapan air atau banjir [3].
Banjir telah menjadi bagian dari masalah masyarakat yang sudah biasa terjadi. Khususnya masyarakat yang tempat tinggalnya berada di wilayah pesisir Kabupaten Demak. Wilayah pesisir Kabupaten Demak terletak dipesisir pantai utara Pulau Jawa rawan. Wilayah pesisir tentu memiliki kerawanan terjadinya kenaikan air laut, banjir, pasang, abrasi, dan akresi. Penyebabnya yaitu wilayah tersebut terletak di wilayah yang memiliki topografi rendah, seperti contohnya wilayah Sayung Kabupaten Demak. Banjir yang terjadi di Kecamatan Sayung salah satunya juga disebabkan oleh pendangkalan Daerah Aliran Sungai.

$$
\text { Daerah Aliran Sungai (DAS) }
$$
memiliki fungsi sebagai tampungan hujan, resapan (penyimpan air), aliran air. Wilayah ini dapat meliputi hulu hingga hilir, kemudian pesisir serta wilayah lindung, budidaya, dan pemukiman warga. Debit puncak terjadi akibat adanya kebun atau tegalan maupun ladang [4]. Faktor yang mempengaruhi debit puncak yaitu faktor hujan dan faktor DAS.

Perkiraan debit puncak DAS Dombo dapat dianalisis dengan meggunakan data curah hujan. Penelitian perkiraan debit puncak pada DAS Dombo sebelumnya telah dianalisis dengan metode HEC-RAS.Adapun hasilnya yaitu dengan periode ulang 100 tahun diperoleh debit banjir rencana pada sungai sepanjang 18.7 $\mathrm{km}$ sebesar $343.0 \mathrm{~m} 3 /$ detik pada sungai Dombo Sayung [1]. Kemudian, analisis terkait debit puncak banjir pada sungai DAS Dombo juga telah dianalisis berdasarkan pada metode HSS Gamma [5]. Pada kajian lain juga telah dilaporkan bahwa metode Rasional, Weduwen Hasper telah dianalisisnya [6]. 
Analisis dilakukan dalam penelitian ini yaitu menganalisis debit puncak banjir pada Sungai DAS Dombo Sayung dengan menggunakan metode Nakayasu dan FSR Jawa Sumatera. Kemudian hasil dari kedua nilai analisis debit tersebut akan dijadikan sebagai rancangan debit banjir pada berbagai kala ulang $(2,5,10,25,50,100,200$ dan 500). Hasil dari penelitian ini diharapkan dapat memberikan informasi kepada masyarakat tentang perkiraan debit banjir yang terjadi.

\section{METODE PENELITIAN}

Penelitian ini menganalisis debit banjir untuk mengevaluasi besar nilai debit banjir di Daerah Aliran Sungai (DAS) Sungai Dombo Sayung, Penggaron dan Dolok Kabupaten Demak. Metode yang digunakan yaitu metode Nakayasu dan FSR Jawa Sumatera. Dalam penelitian ini debit banjir dilakukan pada kala ulang 2, 5 , 10, 25, 50, 100, 200 dan 500 tahun. Adapun proses penelitian dilaksanakan di wilayah DAS Dombo Sayung dengan luas DAS $46.000 \mathrm{~km}^{2}$ dan panjang sungai 19,4 $\mathrm{km}$.

Data dalam penelitian ini yaitu data curah hujan yang telah terhimpun selama 10 tahun yaitu mulai dari 2007 hingga 2016. Kemudian data tersebut diolah dengan tahapan sebagai berikut:

1. Uji konsistensi dilakukan dengan menggunakan metode double mass curve.

2. Analisis frekuensi untuk melakukan penentuan parameter statistik dari data curah hujan maksimum dan minumum menggunakan uji chi square dan smirnov kolmogorov.

3. Menentukan distribusi sebaran
4. Perhitugan hujan rencana dan intensitas hujan dilakukan dengan menggunakan metode mononobe.

5. Perhitungan Debit Puncak Banjir Nakayasu

6. Perhitungan Debit Puncak Banjir FSR Jawa Sumatera

\section{HASIL DAN PEMBAHASAN}

Dalam melakukan analisis hujan rencana dibutuhkan data berupa data curah hujan dari stasiun hujan yang memiliki berpengaruh pada DAS di wilayah dilakukannya penelitian. Data hujan yang digunakan berupa data curah hujan maksimum. Kemudian, metode poligon Thiessen digunakan untuk menganalisis besarnya hujan rerata DAS. Namun sebelum melakukan analisis perhitungan dengan metode poligon Thiessen diperlukan uji konsistensi data. Tujuan uji tersebut yaitu untuk mengetahui kevalidan data dari masing-masing stasiun dapat digunakan. Metode double mass curve dipilih sebagai metode analisis uji konsistensi. Setelah melakukan uji konsistensi maka akan dilakukan analisis perhitungan terkait dengan hujan rerata DAS melalui poligon Thiessen. Adapun analisisnya yang dilakukan adalah sebagai berikut:

1. Hasil Uji Konsistensi

Uji konsistensi pada kajian ini menggunakan metode double mass. Adapun stasiun yang diuji meliputi Stasiun Pucanggading, Brumbung, Banyumeneng, Karangroto, Purwodadi dan Sigotek. Data yang dipilih yaitu data hujan pada periode 2007 hingga tahun 2016 (10 tahun).

Adapun persebaran stasiun dalam penelitian ini disajikan pada Gambar 1. Berdasarkan persebaran stasiun hujan yang digunakan dalam penelitian ini. Maka hasil 
uji nilai konsistensi degan bantuan program Aprob menunjukkan kekonsistensian. Sehingga stasiun yang tersebar dalam Gambar 1 dapat dijadikan sebagai data analisis

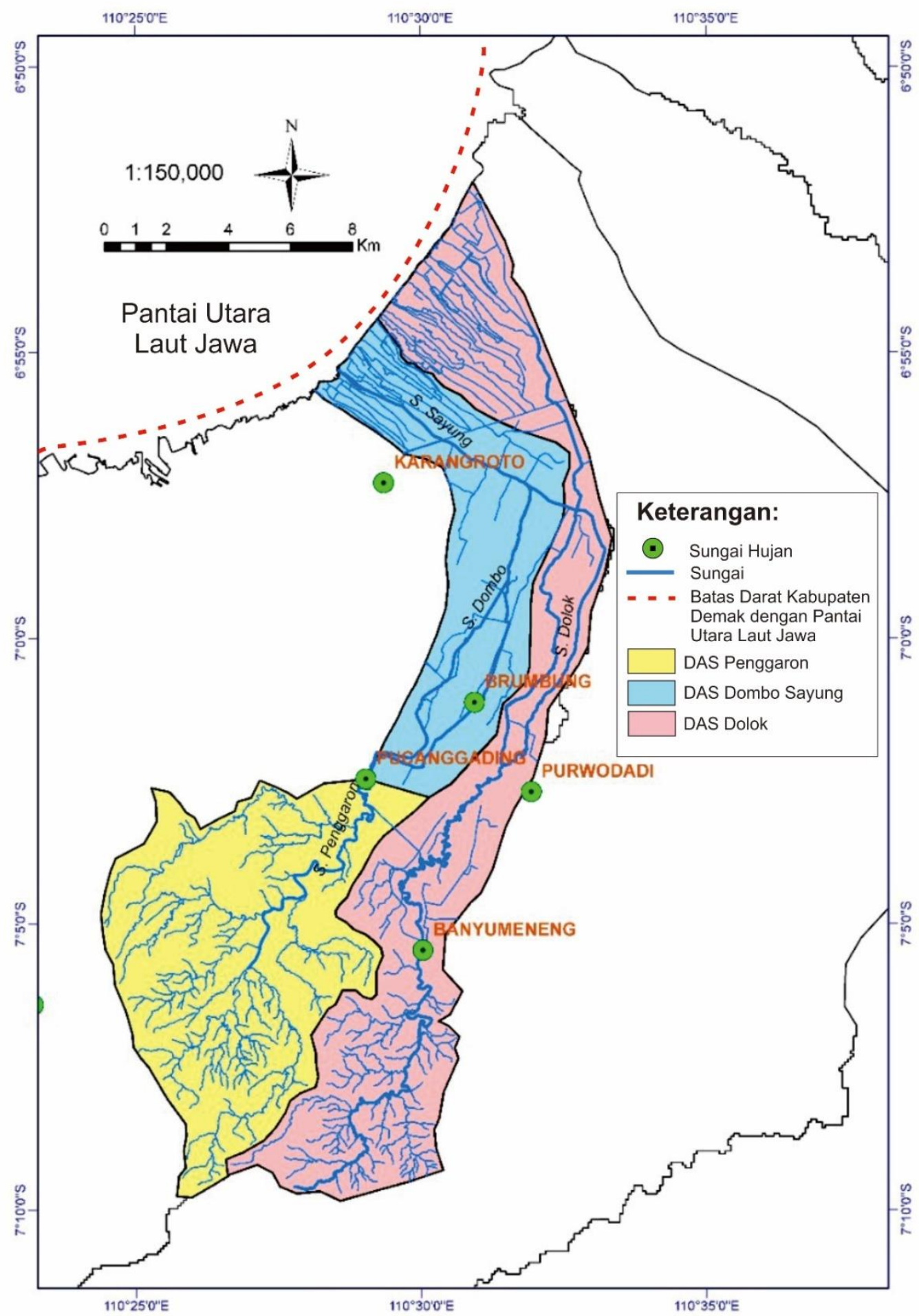

Gambar 1. Persebaran Stasiun Hujan di Wilayah Sungai Penggaron, Dombo Sayung dan Dolok (Sumber: Olah Data, 2019) 
Tabel 1. Jumlah Hujan Harian Pada Masing-Masing Stasiun Hujan Pada Rentang Periode Tahun 2007-2016

\begin{tabular}{ccccccc}
\hline \multirow{2}{*}{ Tahun } & \multicolumn{5}{c}{ Jumlah Hujan Harian (mm) } \\
\cline { 2 - 7 } & Pucanggading & Brumbung & Banyumeneng & Karangroto & Purwodadi & Sigotek \\
\hline 2016 & 2368 & 2433 & 4125 & 2772 & 1597 & 3664 \\
2015 & 1478 & 1712 & 2650 & 1435 & 1280 & 2155 \\
2014 & 2055 & 2703 & 3276 & 2653 & 1358 & 2594 \\
2013 & 2193 & 2244 & 3046 & 2558 & 1869 & 2614 \\
2012 & 2217 & 2209 & 2075 & 2142 & 1623 & 1402 \\
2011 & 2076 & 3106 & 2158 & 1695 & 1606 & 1961 \\
2010 & 2635 & 3106 & 2854 & 2669 & 2450 & 2429 \\
2009 & 2038 & 1896 & 1933 & 1658 & 1323 & 948 \\
2008 & 2990 & 2407 & 2355 & 3003 & 1171 & 2547 \\
2007 & 2191 & 1661 & 1145 & 1735 & 1855 & 13 \\
\hline
\end{tabular}

Tabel 1 merupakan tabel jumlah hujan harian pada masing-masing stasiun yang dipilih berdasarkan pada kelengkapan data hujan. Berdasarkan pada data pada Tabel 1 tersebut maka akan diperoleh grafik konsistensi dengan menggunakan metode double mass yang mempresentasikan kekonsistensian. Nilai kekonsistensian inilah yang akan menentukan stasiun mana saja yang cocok untuk digunakan sebagai data dalam menganalisis debit banjir.

2. Analisis frekuensi

Perhitungan curah hujan rencana diperolah berdasarkan pada parameterparameter statistik. Setelah perhitungan statistik dan logaritmik selesai dilakukan penentuan distribusi apa yang sesuai atau mendekati. Pengujian parameter dilakukan dengan melihat syarat nilai coefisien skewness (Cs) dan coefisien kurtosis (Ck).

Tabel 2. Hujan Harian Maksimum Tahunan

\begin{tabular}{lccc}
\hline & \multicolumn{3}{c}{ Hujan Rerata Maksimum $(\mathrm{mm})$} \\
\cline { 2 - 4 } Tahun & DAS Dombo Sayung & DAS Dolok & DAS Penggaron \\
\hline 2007 & 76 & 61 & 54 \\
2008 & 120 & 76 & 77 \\
2009 & 97 & 78 & 70 \\
2010 & 87 & 73 & 77 \\
2011 & 72 & 57 & 80 \\
2012 & 130 & 71 & 29 \\
2013 & 116 & 87 & 57 \\
2014 & 130 & 124 & 84 \\
2015 & 52 & 109 & 32 \\
2016 & 68 & 128 & 95 \\
\hline
\end{tabular}


Hasil analisis perhitungan frekuensi Sungai, Penggaron, Sungai Dombo Sayung dan Sungai Dolok berdasarkan perhitungan nilai curah hujan maksimum rerata harian telah dianalisis. Hasil analisis daerah menjadi curah hujan rencana menggunakan program Aprob untuk Gumbel, Distribusi Normal, Log Pearson maupun Log Pearson III. Hasil analisis menunjukkan bahwa distribusi yang tepat untuk melakukan analisis yaitu distribusi Log Pearson III.

Sehingga berdasarkan pada analisis tersebut diketahui besar hujan rencana pada periode kala ulang $\mathrm{T}$ Tahun dapat dilihat pada Tabel 3.
3. Distribusi Sebaran

Distribusi sebaran dalam penelitian ini ditentukan dengan menggunakan aplikasi Aprob Berdasarkan hasil perhitungan menggunakan aprob dan pengecekan Uji Chi-Square dan Uji Smirnov-Kolmogorov maka dapat diketahui bahwa distribusi yang tepat

4. Perhitugan Hujan Rencana dan Intensitas

Hujan rencana dalam penelitian ini diperoleh dari distribusi yang memenuhi. Berdasarkan hasil Uji Chi-Square dan Uji Smirnov-Kolmogorov dan distribusi yang sesuai adalah Log Pearson III. Maka, hasil perhitugan hujan rencana dapat dilihat pada Tabel 3.

Tabel 3. Hasil Perhitungan Hujan Rencana dengan Periode Ulang T Tahun

\begin{tabular}{cccc}
\hline $\begin{array}{c}\text { Kala Ulang } \\
(\mathbf{T})\end{array}$ & $\begin{array}{c}\text { Penggaron } \\
(\mathbf{m m} / \mathbf{j a m})\end{array}$ & $\begin{array}{c}\text { Dombo Sayung } \\
(\mathbf{m m} / \mathbf{j a m})\end{array}$ & $\begin{array}{c}\text { Dolok } \\
(\mathbf{m m} / \mathbf{j a m})\end{array}$ \\
\hline 2 & 66 & 93 & 82 \\
\hline 5 & 86 & 119 & 105 \\
\hline 10 & 96 & 134 & 121 \\
\hline 20 & 103 & 146 & 137 \\
\hline 50 & 110 & 161 & 175 \\
\hline 100 & 114 & 172 & 193 \\
\hline 200 & 117 & 181 & 218 \\
\hline 500 & 120 & 193 &
\end{tabular}

Selanjutnya terkait dengan intensitas, maka intensitas hujan dalam penelitian ini dapat dilihat pada Gambar 2 untuk
Sungai Penggaron, Gambar 3 Sungai Dombo Sayung dan Sungai Dolok pada Gambar 4.

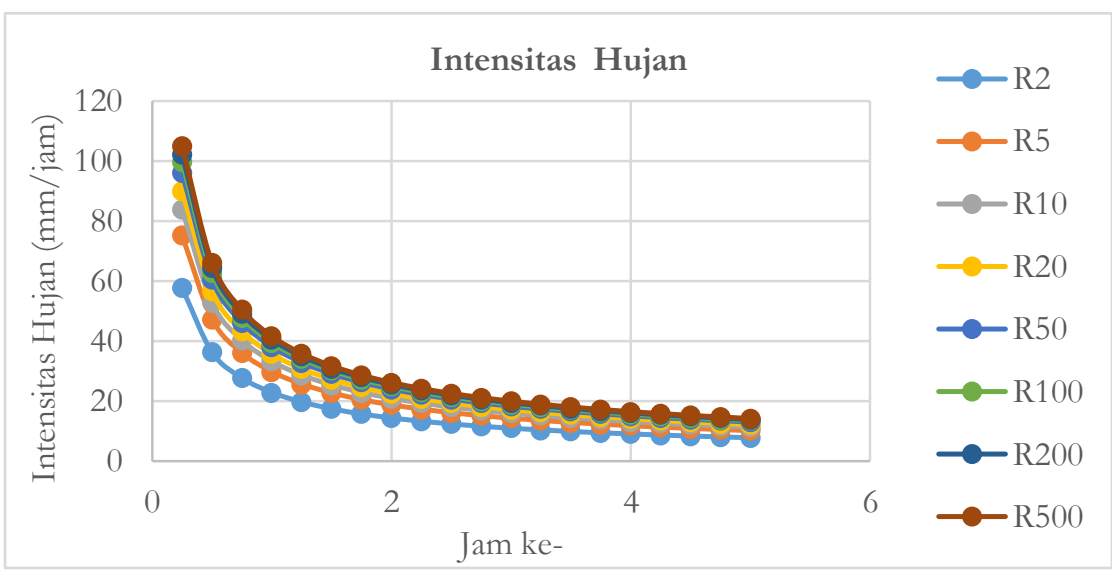

Gambar 2. Intensitas Hujan Sungai Penggaron 


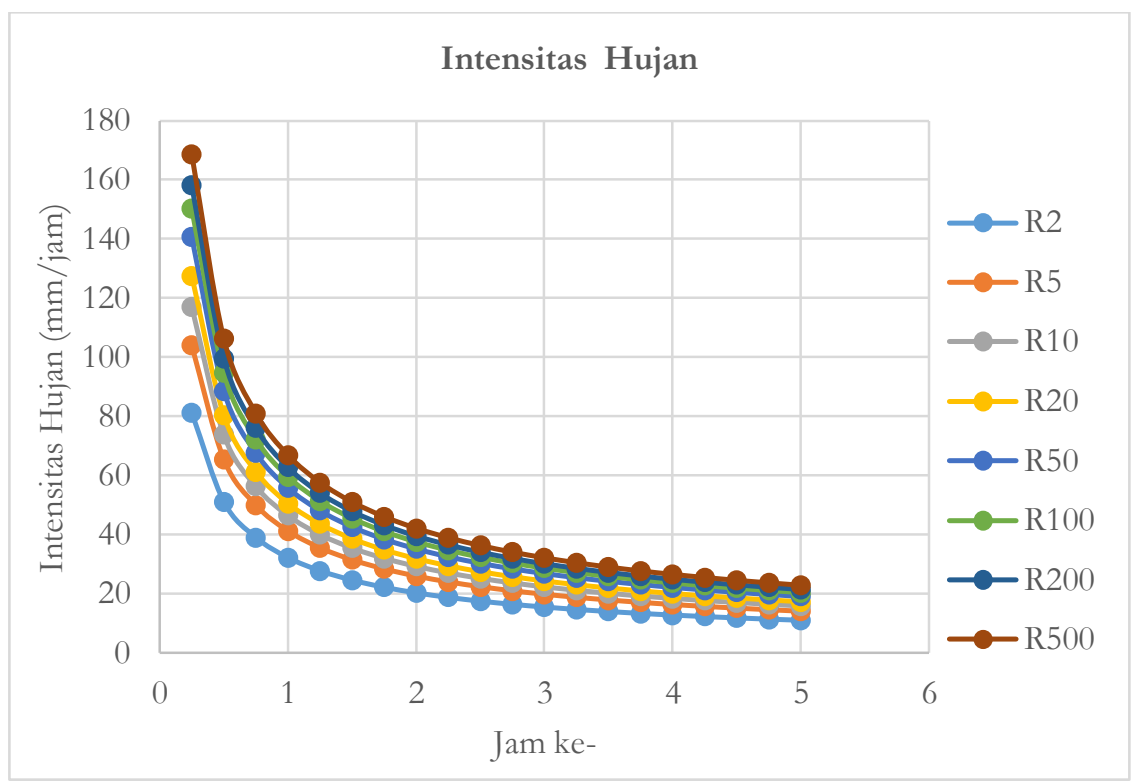

Gambar 3. Intensitas Hujan Sungai Dombo Sayung

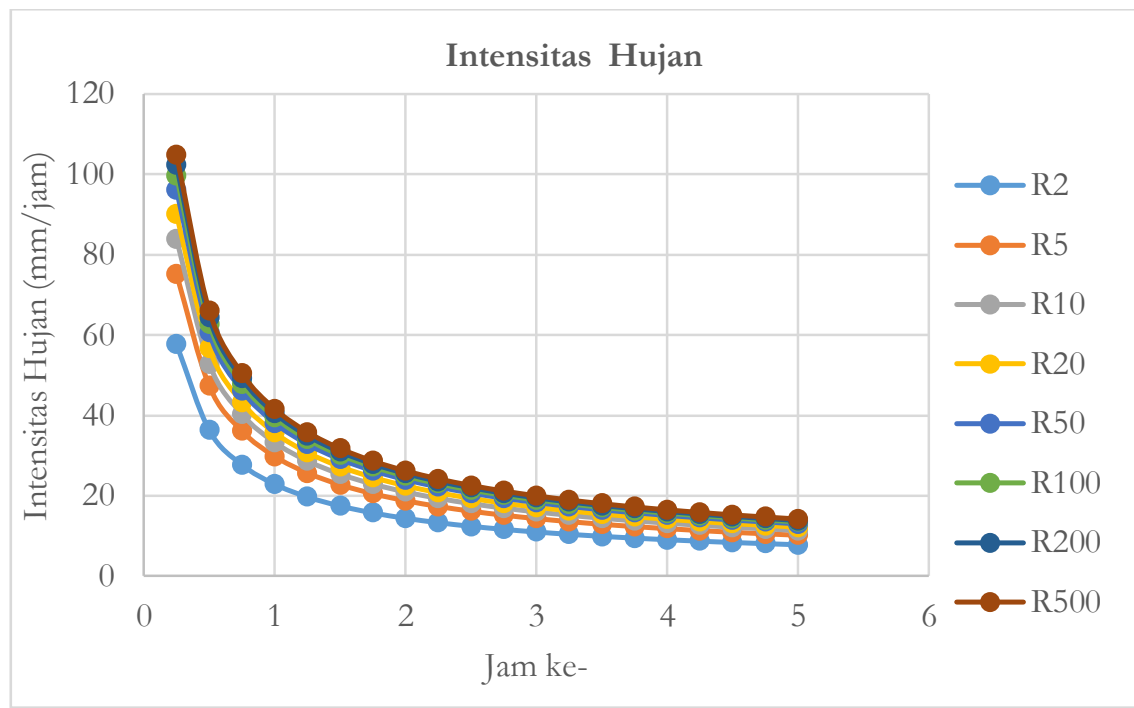

Gambar 4. Intensitas Hujan Sungai Dolok

5. Analisis Debit Banjir

Dalam penelitan ini, analisis debit banjir dihitung berdasarkan pada dua metode yang berbeda yaitu metode Nakayasu dan metode FSR Jawa Sumatera. Setelah dilakukan analisis perhitungan kemudia hasil analisis kedua metode dibandingkan. Berikut adalah persamaanpersamaan untuk melakukan analisis besarnya nilai debit banjir. Pertama yaitu metode Nakayasu sebagai berikut [7].

$$
\mathrm{Qp}=\frac{C A x R o}{3.6\left(0.3 T p+T_{0.3)}\right.}
$$
dengan,Qp : Debit puncak banjir $\left(\mathrm{m}^{3} / \mathrm{dt}\right)$

Ro : Hujan satuan (mm)

Tp : Tenggang waktu permulaan hujan

$\mathrm{T}_{0.3}$ : Waktu yang diperlukan oleh penurunan debit dari puncak hingga $30 \%$ dari debit puncak (jam) 
CA : Luas Daerah Pengaliran banjir dengan periode ulang $\mathrm{T}$ metode Sungai $\left(\mathrm{km}^{2}\right)$

Nakayasu.

Sehingga, berdasarkan pada

persamaan (1), dapat diketahui debit

Tabel 4. Debit Banjir dengan Periode Ulang T Metode Nakayasu

\begin{tabular}{cccc}
\hline \multirow{2}{*}{$\begin{array}{c}\text { Periode } \\
\text { Ulang } \\
\text { (Tahun) }\end{array}$} & $\begin{array}{c}\text { Qt } \\
(\mathbf{m} 3 / \text { detik })\end{array}$ \\
\cline { 2 - 4 } & $\begin{array}{c}\text { Sungai } \\
\text { Penggaron }\end{array}$ & $\begin{array}{c}\text { Sungai Dombo } \\
\text { Sayung }\end{array}$ & $\begin{array}{c}\text { Sungai } \\
\text { Dolok }\end{array}$ \\
\hline 2 & 149.3 & 143.7 & 146.6 \\
\hline 5 & 194.2 & 183.4 & 186.5 \\
\hline 10 & 216.6 & 206.3 & 214.3 \\
\hline 20 & 232.3 & 224.7 & 241.9 \\
\hline 50 & 248.0 & 247.6 & 278.4 \\
\hline 100 & 256.9 & 264.4 & 307.9 \\
\hline 200 & 263.7 & 278.1 & 339.1 \\
\hline 500 & 270.4 & 296.5 & 382.4 \\
\hline
\end{tabular}

Selanjutnya adalah hidrograf hasil analisis metode Nakayasu. Pada Gambar 5, 6 dan 7 ditunjukkan Hidrograf Satuan
Sintesis Nakayasu untuk Sungai Penggaron, Dombo Sayung dan Sungai Dolok.

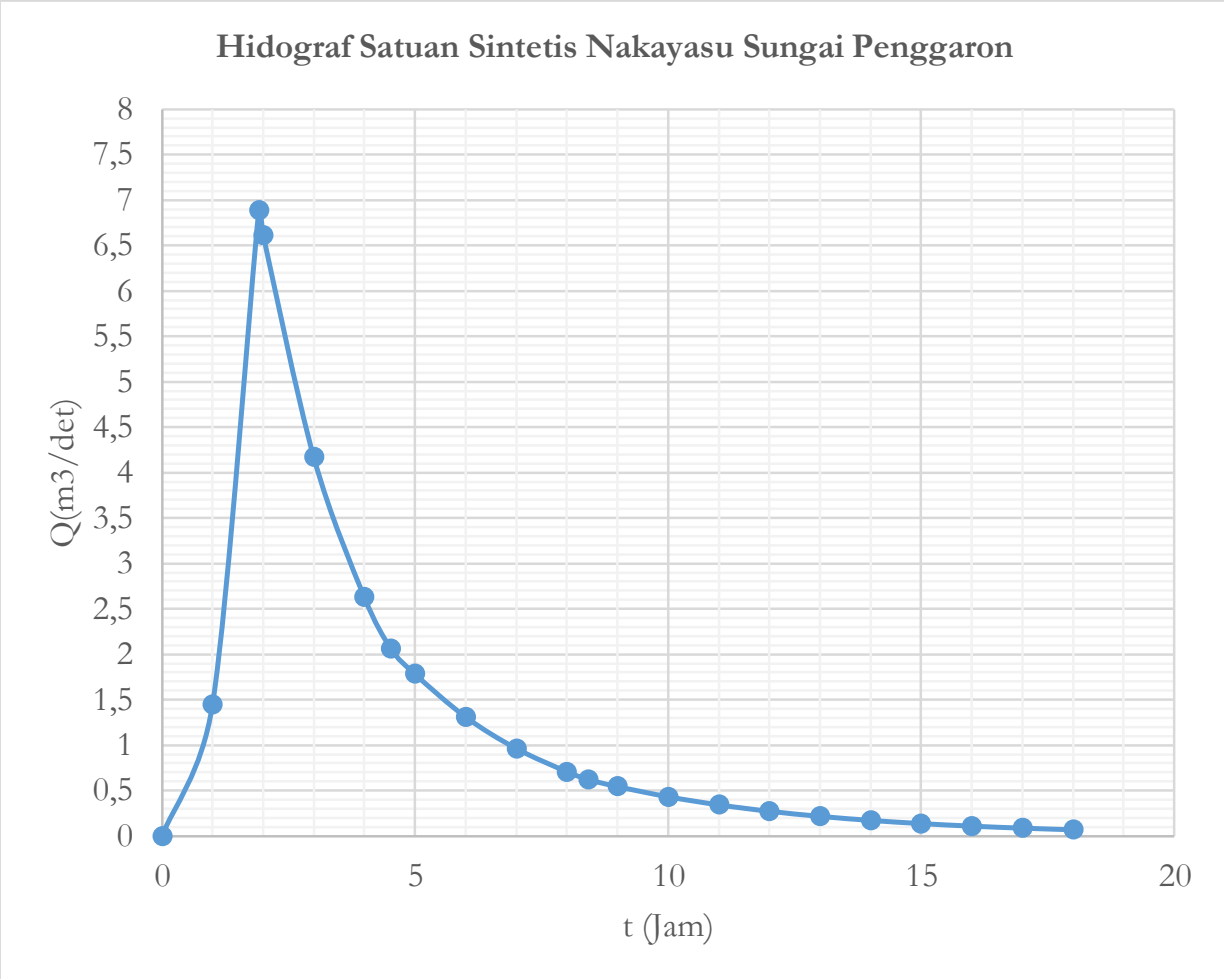

Gambar 5. Hidrograf Nakayasu Sungai Penggaron 


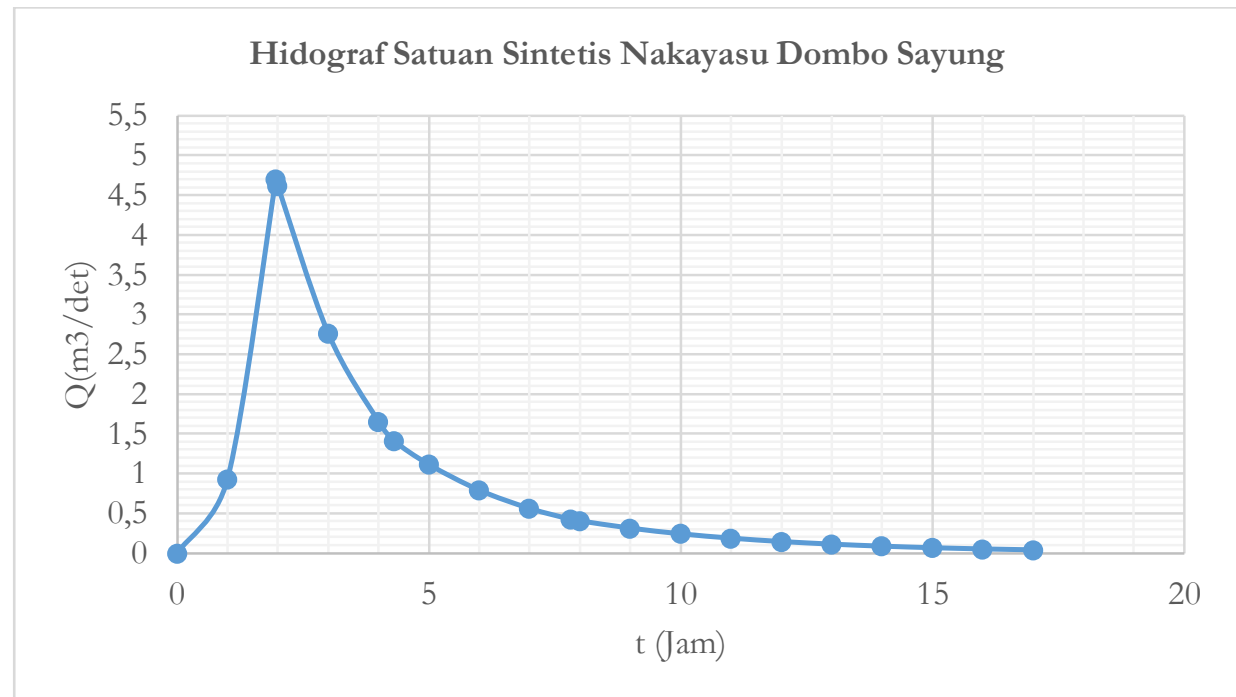

Gambar 6. Hidrograf Nakayasu Sungai Dombo Sayung

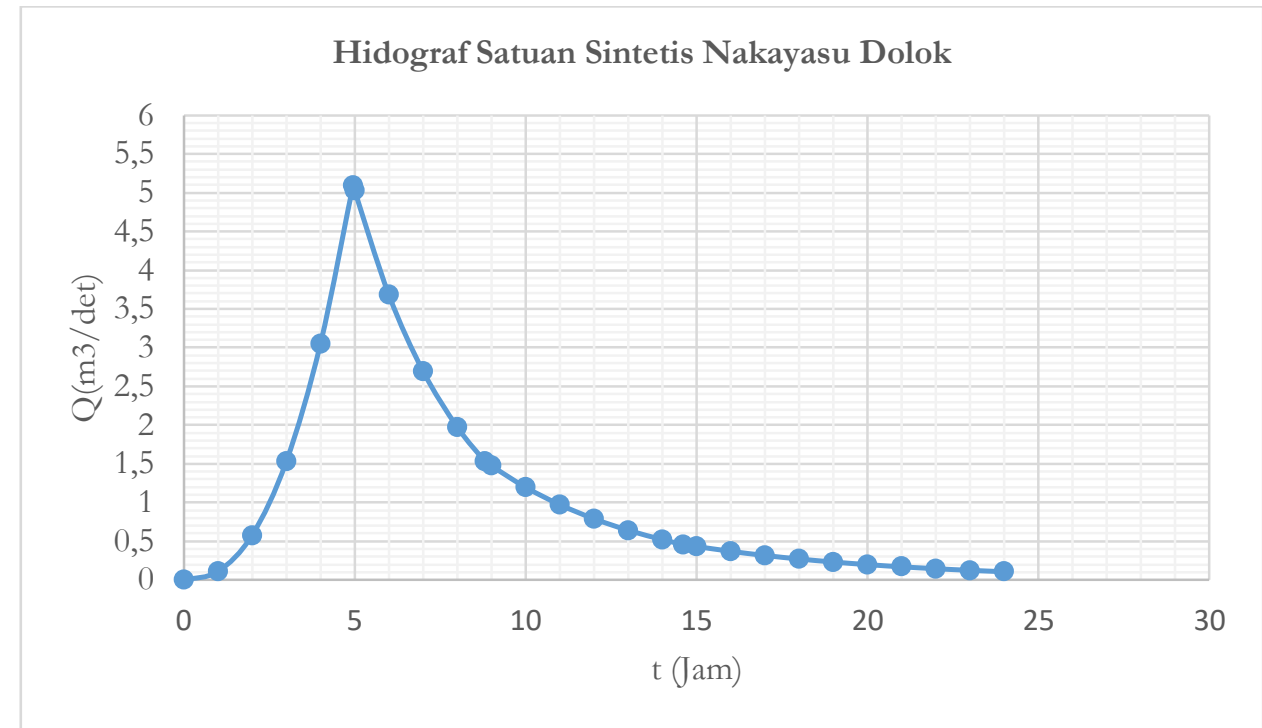

Gambar 7. Hidrograf Nakayasu Sungai Dolok

Selanjutnya analisis debit banjir dengan metode FSR Jawa Sumatera yaitu menggunakan persamaan-persamaan yang ditunjukkan sebagai berikut:

$$
\text { QT }=\text { GF } \times \text { MAF }
$$

dengan, MAF : Debit maksimal rata-rata tahunan

QT : Debit Banjir FSR Jawa Sumatera

GF : Growth factor [8]
Perhitungan QT pada metode FSR Jawa Sumatera diperlukan beberapa parameter seperti luas DAS, hujan rencana, hulu-hilir, panjang sungai. Sungai Penggaron memiliki luas DAS $78,814 \mathrm{~km}^{2}$ dan panjang sungai $12,001 \mathrm{~km}$, hulu hilir 0,0400 km. Sementara untuk Sungai Dombo Sayung luas DAS 49,677 $\mathrm{km}^{2}$ dan panjang sungai $12,457 \mathrm{~km}$, hulu hilir 0,0283 km. Sungai Dolok 98,205 $\mathrm{km}^{2}$ dan panjang sungai $46,52 \mathrm{~km}$, hulu hilir $0,3569 \mathrm{~km}$. Nilai growth factor dalam penelitian ini 0, 1.26, 1.56, 1.88, 2.35, 2.75, 3.27 dan 4.01. Sedangkan nilai MAF diperoleh 
dipengaruhi oleh luas DAS, rata-rata hujan tahunan terbesar, indeks kemiringan, dan faktor reduksi area.

Adapun, nilai faktor reduksi area berdasarkan pada Institute of Hidrology untuk luas Daerah Pengaliran Sungai (DPS) 1-10 $\mathrm{km}^{2}$ yaitu faktor reduksi areanya adalah 0,99. Sedangkan untuk luas DPS 10-30 faktor reduksi areanya 0,97. Kemudian indeks kemiringan diperoleh untuk Sungai Penggaron adalah $0,0038 \mathrm{~m}^{2} / \mathrm{km}$. Sungai Dombo Sayung $0,0025 \mathrm{~m}^{3} / \mathrm{km}$ dan Sungai Dolok $0,0085 \mathrm{~m}^{3} / \mathrm{km}$.

Tabel 5 merupakan hasil analisis debit banjir dengan menggunakan metode FSR Jawa Sumatera DAS Dombo Sayung untuk Sungai Penggaron, Dombo Sayung dan Dolok.

Tabel 5. Hasil Analisis Debit Banjir dengan Periode Kala Ulang T Metode FSR Jawa Sumatra

\begin{tabular}{cccc}
\hline \multirow{2}{*}{$\begin{array}{c}\text { Periode } \\
\text { Ulang } \\
\text { (Tahun) }\end{array}$} & $\begin{array}{c}\text { Sungai } \\
\text { Penggaron }\end{array}$ & $\begin{array}{c}\text { Qt } \\
(\mathbf{m} / \text { detik })\end{array}$ \\
\hline 2 & $\begin{array}{c}\text { Sungai } \\
\text { Dombo } \\
\text { Sayung }\end{array}$ & $\begin{array}{c}\text { Sungai } \\
\text { Dolok }\end{array}$ \\
\hline 5 & 0 & 0 & 0 \\
\hline 10 & 25.7 & 23.1 & 33.3 \\
\hline 20 & 36.4 & 38.2 & 58.3 \\
\hline 50 & 53.4 & 56.8 & 95.2 \\
\hline 100 & 68.2 & 124.0 & 168.6 \\
\hline 200 & 86.4 & 167.1 & 383.3 \\
\hline 500 & 112.7 & 239.7 & 632.1 \\
\hline
\end{tabular}

Hasil perbandingan debit banjir metode Nakayasu dan FSR Jawa Sumatera dapat dilihat pada Tabel 6. Jika ditinjau berdasarkan pada nilai kala ulang debit banjir pada Sungai Penggaron, Dombo Sayung dan Dolok yang dianalisis dengan menggunakan Metode Nakayasu telah mampu mendeteksi keberadaan debit banjir. Akan tetapi saat dianalisis menggunakan FSR Jawa Sumatra pada kala ulang 2 tahun belum terdeteksi seberapa besar rencana debit banjir yang terjadi di masing-masing sungai.

Dengan demikian, maka hasil analisis debit banjir rencana menggunakan metode Nakayasu dan FSR Jawa Sumatera menunjukkan adanya perbedaan. Berdasarkan pada hasil penelitian yang telah dilakukan terdapat Perbedaan hasil analisis kemungkinan dipengaruhi oleh parameter pengukuran yang berbeda. Dimana, parameter yang berpengaruh pada analisis Nakayasu yaitu nilai tenggang waktu dari permukaan hujan sampai puncak hidrograf atau disebut dengan time of peak. Kemudian tenggang waktu dari titik berat hujan sampai titik berat hidrograf atau disebut sebafai time lag. Selanjutnya tenggang waktu hidrograf atau disebut dengan time base of hydrograph, luas daerah aliran sungai, dan panjang aliran sungai. Sedangkan pada FSR Jawa Sumatera parameter yang digunakan diantaranya luas DAS, panjang sungai, indeks danau, indeks kemiringan, growth factors, rata-rata hujan tahunan terbesar, hulu dan hilir.

Selain itu, faktor klimatologi juga berpengaruh pada nilai debit banjir. Peningkatan debit banjir dari waktu kewaktu diprediksi mengalami peningkatan yang semakin besar. Hal ini salah satunya dipengaruhi oleh iklim. Pada kajian yang dilakukan oleh Prasetyo dkk (2018) disebutkan bahwa perubahan iklim memberi dampak negatif pada lingkungan. Salah satunya adanya kenaikan permukaan laut. Sehingga, kenaikan ini dapat menyebabkan daratan mengecil. Salah satunya di wilayah Demak [9]. Nilai debit banjir akan sangat deras jika kecepatan air yang mengalir juga tinggi sehingga berlangsung cepat dan jumlah air sedikit. 
Pada umumnya banjir yang diakibatkan pada kondisi tersebut memiliki sifat yang destruktif. Sehingga jika didasarkan pada hasil perhitungan dapat diperkirakan pada kala ulang 500 tahun debit banjir terbesar akan terjadi dengan kemungkinan dapat menyebabkan terjadinya kerusakan [10].

Tabel 6. Perbandingan Metode Nakayasu dan FSR Jawa Sumatra

\begin{tabular}{ccccccc}
\hline \multirow{2}{*}{$\begin{array}{c}\text { Kala Ulang } \\
\text { (Tahun) }\end{array}$} & \multicolumn{2}{c}{ Sungai Penggaron } & \multicolumn{2}{c}{ Sungai Dombo Sayung } & \multicolumn{2}{c}{ Sungai Dolok } \\
\cline { 2 - 7 } & Nakayasu & $\begin{array}{c}\text { FSR Jawa } \\
\text { Sumatra }\end{array}$ & Nakayasu & $\begin{array}{c}\text { FSR Jawa } \\
\text { Sumatra }\end{array}$ & Nakayasu & $\begin{array}{c}\text { FSR Jawa } \\
\text { Sumatra }\end{array}$ \\
\hline 2 & 149.3 & 0 & 143.6 & 0 & 146.6 & 0 \\
\hline 5 & 194.2 & 15.7 & 183.4 & 23.1 & 186.5 & 33.3 \\
\hline 10 & 216.6 & 25.4 & 206.3 & 38.2 & 214.2 & 58.3 \\
\hline 20 & 232.3 & 36.4 & 224.6 & 56.8 & 241.9 & 95.2 \\
\hline 50 & 248.0 & 53.4 & 247.5 & 90.2 & 278.3 & 168.6 \\
\hline 100 & 256.9 & 68.2 & 264.3 & 124.0 & 307.8 & 253.7 \\
\hline 200 & 263.7 & 86.4 & 278.1 & 167.1 & 339.1 & 382.7 \\
\hline 500 & 270.4 & 112.7 & 296.4 & 239.7 & 382.2 & 632.1 \\
\hline
\end{tabular}

\section{KESIMPULAN}

Hasil analisis menunjukkan bahwa terdapat perbedaan nilai debit banjir pada DAS Penggaron, Dombo Sayung, Dolok. Jika ditinjau berdasarkan pada kala ulang debit banjir pada masing-masing sungai yang dianalisis dengan menggunakan Metode Nakayasu telah mampu mendeteksi keberadaan debit banjir, akan tetapi saat dianalisis dengan menggunakan FSR Jawa Sumatra pada kala ulang 2 tahun belum terdeteksi seberapa besar rencana debit banjir yang terjadi di masing-masing sungai.

Debit banjir rencana yang dianalisis melalui dua metode tersebut memiliki perbedaan. Dimana metode Nakayasu dapat menunjukkan nilai debit meskipun di kala ulang 2 Tahun. Sementara untuk metode FSR Jawa Sumatera tidak menunjukkan adanya nilai debit banjir.

Adapun, hasil penelitian menunjukkan bahwa debit banjir yang dianalisis dengan menggunakan metode Nakayasu menghasilkan debit banjir yang lebih besar daripada analisis debit banjir menggunakan FSR Jawa Sumatera.

\section{DAFTAR PUSTAKA}

[1] Arahman, Iman. "Pengendalian Banjir Sungai Dombo Sayung Kabupaten Demak", Jurnal Karya Teknik Sipil Volume 4 (1), (135144), 2015.

[2] R. P. Sembiring, U. S. Hardjanto, and S. A. G. Pinilih, "Pencegahan Dan Penanggulangan Banjir Dan Rob Menurut Peraturan Daerah Kota Semarang Nomor 14 Tahun 2011 Tentang Rencana Tata Ruang Wilayahkota Semarang Tahun 20112031," Diponegoro Law Journal, vol. 8, no. 1, pp. 664-687, Jan. 2019.

[3] Maryanti,Setty, “IdentifikasiPengguna an Lahan Terhadap Pendangkalan Sungai Wonokerto Kecamatan Karangtengah Kabupaten Demak" Surakarta: Prosiding Seminar Nasional Geografi UMS IX, 2018.

[4] Alhakim, Euis E., Abimanyu Bondan WS., Eko Rudi Iswanto, "Perbandingan Hidrograf Satuan Sub-DAS Cisadane untuk Analisis Banjir Tapak RDNK Serpong", 
Jurnal Pengembangan Energi Nuklir

Vol. 21, No. 2, 97-104, 2019

[5] G. Pitanggi, I. Lestari, S. Darsono, and S. Salamun, "Normalisasi Sungai Dolok Semarang - Demak, Jawa Tengah," Jurnal Karya Teknik Sipil, vol. 6, no. 4, pp. 367-376, Dec. 2017.

[6] A. Ma'rruf, A. Graha, S. Salamun, and I. Ismiyati, "Pengembangan Sungai Banjir Kanal Timur Semarang Sebagai Transportasi Sungai Untuk Tujuan Wisata," Jurnal Karya Teknik Sipil, vol. 4, no. 4, pp. 107-120, Nov. 2015.

[7] Bambang Triatmodjo "Hidrologi Terapan”, Yogyakarta: Beta Offset, 2008

[8] Loebis, Joesron."Banjir Renana Bangunan Air", Jakarta: Yayasan Badan Penerbit PU, 1987

[9] Y Prasetyo., N Bashit., B Sasmito dan W Setianingsih.'Impacct of Land Subsidence and Sean Level Rise Influence Shoreline Change in The Coastal Area of Demak" The 4th International Conference of Indonesian Society for Remote Sensing IOP Conf. Series: Earth and Environmental Science 280

[10]Santosa, Wicke Widyanti., Andri Suprayogi., Bambang Sudarsono. "Kajian Pemetaan Tingkat Kerawanan Banjir Dengan Menggunakan Sistem Informasi Geografis (Studi Kasus : DAS Beringin, Kota Semarang)" Jurnal Geodesi Undip Volume 4, Nomor 2, Halaman 185-190, 2015. 